\title{
Effectiveness of peers and faculty feedback on students performance
}

\author{
Amruta S Bennal ${ }^{1, *}$, R. H Takllikar ${ }^{2}$, Rashmi $^{3}$ \\ ${ }^{1}$ Assistant Professor, ${ }^{2}$ Professor \& HOD, ${ }^{3}$ Associate Professor, Dept. of Physiology, ${ }^{1}$ Raichur Institute of Medical Sciences, \\ Raichur, Karnataka, ${ }^{2,3}$ Navodaya Medical College, Raichur Karnataka, India
}

*Corresponding Author:

Email: amrutabennal@gmail.com

Received: $03^{\text {rd }}$ October, 2017

Accepted: $30^{\text {th }}$ January, 2018

\begin{abstract}
Introduction: In medical education, an integral and important element of teaching is feedback, as it encourages and enhances the learners knowledge, skills and professional performance.

Aims and Objective:-To know the effectiveness of feedback to students practical (clinical) skills, and students perception towards the feedback session.

Materials and Methods: A interventional and comparative study was conducted in 50 first year MBBS medical students admitted during year 2015-16. 33 students received the feedback and 17 students out of 50 students were randomly selected for not receiving feedback.

Results: There was high significant change in scores obtained with post feedback $(\mathrm{P}<0.0001)$ and also with the students who received the feedback. $(\mathrm{P}<0.0001)$ All the students felt that this is the better modality for enhancing the practical skills.

Conclusion: Appropriate feedback is necessary for improving the skills and it can have very powerful effect on learning.
\end{abstract}

Keywords: Feedback, Students, Physiology.

\section{Introduction}

In medical education, an integral and important element of teaching is feedback, as it encourages and enhances the learners knowledge, skills and professional performance. It aids in improvement of the performance of the learners with the basic aim of helping them achieve their goals in addition to the educational objectives. ${ }^{1,2}$ Feedback is specific informaton about the comparision between a trainees observed performance and a standard, given with the intent to improve the trainees performance by the observer. Feedback can be considered as constructive in the process of learning if it is delivered immediately and in a sensitive manner. ${ }^{3,4}$ It is well documented that in academic settings, students learn more effectively when peer feedback is an inherent constituent of the overall assessment. ${ }^{5}$

Physiology is the link between the basic sciences and medicine which is taught to the first year MBBS medical students in their medical course. ${ }^{6}$ Students learn human physiology by attending theory and practical classes. During practical, clinical physiology is also taught, which helps to learn the clinical skills for becoming good and competent practitioner. The education process in medical colleges is aiming, in its broad term, to produce a competent general practitioner oriented to the health problems of the community. ${ }^{7,8}$ Many researchers have demonstrated the potency of feedback as a mechanism to improve learning outcome ${ }^{9}$ and feedback holds the potential to positively influence learning by prompting active involvement with the material to be learned. ${ }^{10}$ So we have taken this study, to know the effectiveness of feedback to their practical(clinical) skills, and students perception towards the feedback session.

\section{Materials and Methods}

This interventional and comparative study was conducted in the Department of Physiology, Navodaya medical college (NMC) Raichur. The study and its conduct were cleared by the ethical committee, NMC Raichur. It was conducted in the month of January and February 2016, before the second internal assessment during the revision classes. The study included 50 (batch $\mathrm{C}$ and D) first year medical students admitted to the course $2015-16$.

After obtaining the informed consent, all the volunteers were made to sit in clinical practical hall. 17 students out of 50 students were randomly selected as controls for not receiving feedback. All the volunteers of the respective batch were made to sit in a semicircle. The question components those will be kept in university exam were given to the individual students. 5 minutes of time was given to them to analyze the component and explained about the domains (knowledge, attitude and performance) which are going to be assessed. Each individual student was made to perform the allotted component and feed back was collected from other students who were observing the performance and the facilitator summarized and explained the points those were missed by the students and score was given to the student. After the procedure, student perception regarding the procedure (feedback session) was collected through questionnaire method 
which were validated by pilot study. Even students were asked to give open comments regarding the feedback sessions. As the part of course, the second internal assessment was conducted. The same set of clinical questions were given to the students. Scores obtained by the students of batch $\mathrm{C}$ and $\mathrm{D}$ for the clinical experiment in the second internal assessment were taken for analysis.

Table 1: The components assessed and given feedback

\begin{tabular}{|c|c|c|}
\hline Domains & Activity & Score \\
\hline \multirow[t]{2}{*}{$\begin{array}{l}\text { Communication skills } \\
(05)\end{array}$} & $\begin{array}{l}\text { Able to introduce themselves and } \\
\text { able to know the identity of subject } \\
\text { examining }\end{array}$ & \\
\hline & Able to give proper instruction & \\
\hline \multirow[t]{2}{*}{ Performance (10) } & $\begin{array}{l}\text { Able to identify the instrument and } \\
\text { hold it properly }\end{array}$ & \\
\hline & Perform the procedure correctly & \\
\hline \multirow[t]{3}{*}{$\begin{array}{l}\text { Interpretation of results } \\
\text { (knowledge) }(05)\end{array}$} & Able to do interpret the results & \\
\hline & $\begin{array}{l}\text { Able to tell two to three conditions } \\
\text { related that procedure }\end{array}$ & \\
\hline & Total score $(20)$ & \\
\hline
\end{tabular}

\section{Statistical Analysis}

The results were expressed in terms of Mean \pm SD. The test of significance used was student " $\mathrm{t}$ " test (paired t-test and unpaired t-test) and a p-value and a "p' value less than 0.05 was considered statistically significant. The data was analyzed by using SPSS 17.0 version statistical software. Microsoft Word and Excel have been used to generate graphs, tables etc.

\section{Results}

The interventional and comparative study was conducted in the department of Physiology for the first year medical students admitted during the academic year 2015-2016. 50 students were enrolled for the study. (C and D batch with 25 students) 33 students received feedback and 17 students out of 50 students, randomly selected for not receiving the feedback. The scores of pre- and post feedback session are represented in table 2 and the scores for the students who received feedback and who did not receive feedback is represented in table 3 . There is statistically significant difference in the scores obtained pre and post feedback and also between the students who received the feedback and who did not received the feedback.

Table 2: The scores of pre and post feedback

\begin{tabular}{|c|c|c|c|c|l|}
\hline Parameter & $\begin{array}{c}\text { Post- feedback } \\
\text { scores }(\text { Mean } \pm \text { SD] }\end{array}$ & $\begin{array}{c}\text { Pre-feedback scores } \\
(\text { Mean } \pm \text { SD] }\end{array}$ & 't' value & 'p' value & Significance \\
\hline Scores $(20)$ & $\begin{array}{c}13.79 \pm 1.709 \\
(\mathrm{~N}=33)\end{array}$ & $\begin{array}{c}10.54 \pm 3.143 \\
(\mathrm{~N}=33)\end{array}$ & 5.568 & $\mathrm{P}<0.0001$ & $\begin{array}{l}\text { Highly } \\
\text { significant }\end{array}$ \\
\hline
\end{tabular}

Table 3: The Scores for the students who received feedback and who did not receive feedback

\begin{tabular}{|l|c|c|c|c|c|}
\hline Parameter & $\begin{array}{c}\text { Attended the } \\
\text { feedback session } \\
\text { (cases)[Mean } \pm \text { SD] }\end{array}$ & $\begin{array}{c}\text { Did not attend the } \\
\text { feedback session } \\
\text { (controls)[Mean } \pm \text { SD] }\end{array}$ & 't' value & 'p' value & Significance \\
\hline Scores $(20)$ & $13.79 \pm 1.709(\mathrm{~N}=33)$ & $11.53 \pm 1.624(\mathrm{~N}=17)$ & 4.498 & $\mathrm{P}<0.0001$ & $\begin{array}{c}\text { Highly } \\
\text { significant }\end{array}$ \\
\hline
\end{tabular}

All the students felt that this is the better modality for enhancing the practical skills. Perception regarding the feedback session is represented in table 4 , in the form of percentage.

Table 4: Perception regarding the feedback session

\begin{tabular}{|l|c|c|}
\hline \multicolumn{1}{|c|}{ Parameter } & Yes & No \\
\hline Was this session interesting? & $97 \%$ & $3 \%$ \\
\hline Is this a better modality for enhancing the skills during revision of practical? & $100 \%$ & 0 \\
\hline Is there involvement of your colleagues in this session? & $94 \%$ & $6 \%$ \\
\hline Is it helpful for enhancing the knowledge? & $97 \%$ & $3 \%$ \\
\hline Will this session enhance your confidence while doing the practical? & $100 \%$ & 0 \\
\hline
\end{tabular}




\begin{tabular}{|l|c|c|}
\hline $\begin{array}{l}\text { Do you think, your doubts about any procedure will be cleared by this way of } \\
\text { teaching? }\end{array}$ & $97 \%$ & $3 \%$ \\
\hline Has it given motivation for learning? & $97 \%$ & $3 \%$ \\
\hline
\end{tabular}

\section{Discussion}

This interventional and comparative study was conducted in the department of physiology to know the effectiveness of feedback on students performance as it is important for students to know how well they are doing as they learn. This is because the knowledge that they are doing well gives students a sense of achievement which motivates them to learn more. In the absence of feedback from teachers, learners have to rely on self-assessment to determine what has gone well and what needs improvement. Feedback can be given to individual students, to a group of them, or to the whole class. It would be more efficient if the whole class can share in the monitoring process and the feedback. In our study, whole batch was involved in the process of feedback session.

The scores obtained by the students after feedback session were higher comparing to the scores obtained prior and scores obtained by the students who receive feedback are higher than the those who did not get the feedback. Our studies are similar to the studies done by Tae Seob Shin ${ }^{11}$ Anastasiya A. Lipnevich ${ }^{10}$ with little bit modification in methodology. In one study they have observed "The Effects of Peer- and SelfReferenced Feedback on Students' Motivation and Academic Performance in Online Learning Environments"11 and in another study observed "Effects of Differential Feedback on Students' Examination Performance" 10

The art of giving feedback to medical students about their performance and competence can act as a strong motivating factor. ${ }^{12}$ Many students agreed that it gives motivation for learning. In order for assessment to facilitate learning, students need to receive information about the discrepancy between the actual and the desired state. This information is commonly referred as feedback. ${ }^{13,14}$

The detailed, specific, descriptive feedback that focuses students' attention on their work, rather than on the self, is the most advantageous approach to formative feedback. The benefits of such feedback occur at all levels of performance. Feedback should also be given to students as frequently as possible. Ideally, a student should receive feedback for each and every assigned task in the process of acquiring proficiency with new material. Teachers should try to give feedback in a positive manner as positive feedback not only provides more information than negative ones but it also helps to strengthen a student's motivation and self-esteem. A positive approach should also be adopted when providing students with feedback on their mistakes.
Feedback provides learners with information on past performances so that future performance can be improved. In the absence of adequate feedback, good performance is not recognized and problems with regard to clinical competence go uncorrected for long periods of time. The usefulness of giving constructive feedback privately to medical students at the time of bedside teaching has been well documented and is found effective in acquiring and developing clinical skills, communication skills and professional bedside manner by medical students. ${ }^{15,16}$ Most of the students felt, their confidence level will increase after feedback and their doubts can be cleared and it is very useful to learn the skills correctly. Most of the students felt that, after every practical session, during revision practical, they need feedback, so that their skill and confidence level can increased.

\section{Conclusion}

Appropriate feedback is necessary for improving the skills as feedback provides learners with information on past performances, so that future performance can be improved and it can have very powerful effect on learning.

\section{Acknowledgement}

Thanks to the first phase medical students of 2015 16 batch, who became volunteers for the study.

\section{References}

1. Schartel, S. Giving feedback - an integral part of education. Best Practice \& Research Clinical Anaesthesiology, 2012. 26(1),77-87.

2. Thomas, J. D. and Arnold, R. M. Giving feedback Journal of Palliative Medicine, 2011:14(2),233-9.

3. Nicol, D. and MacFarlane-Dick, D. Rethinking formative assessment in HE: A theoretical model and seven principles of good feedback practice. Studies in Higher Education, 2006. 31(2),199-218.

4. Sargent, J., Mann, K., Sinclair, D., et al. Challenges in multisource feedback: Intended and unintended outcomes. Medical Education2007:41(6),583-91.

5. Van den Berg, I., Admiraal, W., Pilot, A. Peer assessment in university teaching: Evaluating seven course designs. Assessment and Evaluation in Higher Education, 2006;31(1),19-36.

6. Amruta Bennal, Manohar Pattar, R H Taklikar. Effectiveness of "case -based learning" in physiology. National Journal of Physiology, Pharmacy and Pharmacology, 2016; vol 6 issue(1),65-7.

7. The World Conference on Medical Education. The main subjects for discussion.Med Ed 1988;22:483-7.

8. Waleed A. Milaat MD, $\mathrm{PhD}(\mathrm{UK})$., Fathi M. El-Gamal $\mathrm{MD}, \mathrm{PhD}(\mathrm{UK})$. Factors Affecting The Use And Attitude Towards Medical Resources And Educational Methods In 
A Saudi Medical School. Ann Saudi Med 1994;14(3):209-14.

9. Hattie, J. and Timperley, H. The power of feedback. Review of Educational Research, 2007:77(1),81-112.

10. Anastasiya A. Lipnevich. Jeffrey K. Smith. Effects of Differential Feedback on Students' Examination Performance. Journal of Experimental Psychology Applied, 2009;Vol- 15, No. (4),319-33.

11. Tae Seob Shin. W. Patrick Dickson. The Effects of Peerand Self-Referenced Feedback on Students' Motivation and Academic Performance in Online Learning Environments. MERLOT Journal of Online Learning and Teaching. Vol. 6, No. 1, March 2010.

12. Kusurkar, R. Motivation in medical students: a PhD thesis report. Perspectives on Medical Education 2012:1(3), 155-157.

13. Ilgen, D. R., Davis, C. A. Bearing bad news: Reactions to negative performance feedback. Applied Psychology: An International Review, 2000:49,550-65.

14. Kluger, A. N., DeNisi, A. The effects of feedback interventions on performance: Historical review, a metaanalysis, and a preliminary feedback intervention theory. Psychological Bulletin, 1996; Vol-119, 254-284.

15. Kianmehr, N., Mofidi, M., Yazdanpanah, R., et al. Medical student and patient perspectives on bedside teaching. Saudi Medical Journal, 2010; 31(5),565-8.

16. Salam, A., Siraj, H. H., Mohamad, N., et al. Bedside teaching in undergraduate medical education: issues, strategies, and new models for better preparation of new generation doctors. Iranian Journal of Medical Sciences: 2011:36(1),1-6. 